\title{
Micronutrient Availability in Fresh and Aged Douglas Fir Bark
}

\author{
M. Gabriela Buamscha ${ }^{1}$ \\ Crop and Soil Science Department, Oregon State University, 3017 Ag. Life \\ Sciences Bldg., Corvallis, OR 97331
}

James E. Altland ${ }^{2,4}$

Department of Horticulture, Oregon State University, North Willamette Research and Extension Center, 15210 NE Miley Road, Aurora, OR 97002

\author{
Daniel M. Sullivan ${ }^{3}$ \\ Crop and Soil Science Department, Oregon State University, 3049 Ag. Life \\ Sciences Bldg., Corvallis, OR 97331

\section{Donald A. Horneck ${ }^{3}$ \\ Crop and Soil Science Department, Oregon State University, P.O. Box 105, Hermiston, OR 97838}

Additional index words. Pseudotsuga menziesii, Catharanthus roseus, annual vinca, composted yard debris, Micromax, container substrate, media

Abstract. Annual vinca [Catharanthus roseus (L.) G. Don 'Peppermint Cooler'] plugs were transplanted to containers filled with Douglas fir [Pseudotsuga menziesii (Mirbel) Franco] bark (DFB) in May and June 2005 (Expts. 1 and 2, respectively). Treatments were arranged in a $2 \times 3$ factorial with two DFB ages (fresh and aged) and three micronutrient sources (DFB alone, $10 \%$ by volume yard debris compost, or $0.9 \mathrm{~kg} \cdot \mathrm{m}^{-3}$ Micromax fertilizer). Plants were measured for shoot dry weight and foliar color. Substrate and foliar samples of each plant were analyzed for 13 essential macro- and micronutrients plus substrate $\mathbf{p H}$ and EC. Douglas fir bark alone appears to provide sufficient micronutrients for annual vinca grown at $\mathrm{pH} 4.7$ to 5.7 over a 2 -month period. In Expt. 1 there were no differences in shoot dry weight or foliar color regardless of DFB age or micronutrient source. At the end of Expt. 2, plants in aged DFB were larger than those in fresh DFB, but differences were primarily the result of nitrogen availability. None of the treatments developed color symptoms that could be associated with micronutrient deficiency. Micronutrient availability in DFB should be considered in container fertilizer management plans.

Container crops in the Pacific Northwest (PNW) are grown primarily in Douglas fir [Pseudotsuga menziesii (Mirbel) Franco] bark (DFB). Similar to pine (Pinus taeda L.) bark in the southeast U.S., DFB comprises the highest portion of most nursery substrates $(60 \%$ to $80 \%$ of the substrate mix, personal observation) and is often incorporated to some extent with peatmoss, sand, compost, pumice, and other materials, including fertilizers.

Fresh and aged DFB are used in Oregon (OR) container nurseries. Fresh DFB refers to material sold soon after bark is removed from the tree, ground to smaller particle size, and

Received for publication 7 Aug. 2007. Accepted for publication 20 Sept. 2007.

We thank the Oregon Association of Nurseries for funding this research and Gilda Medina, Vyacheslav Dobryk, and Magdalena Zazirska for skillful technical assistance.

${ }^{1}$ Graduate research assistant.

${ }^{2}$ Assistant professor.

${ }^{3}$ Associate professor

${ }^{4}$ To whom reprint requests should be addressed; e-mail James.Altland@oregonstate.edu. fertility. However, research has shown that pine bark media contains sufficient micronutrients to produce woody plants. Niemiera (1992) extracted slightly lower levels of copper $(\mathrm{Cu})$, iron $(\mathrm{Fe})$, manganese $(\mathrm{Mn})$, and zinc $(\mathrm{Zn})$ from pine bark alone compared with pine bark amended with Micromax (The Scotts Co., Marysville, Ohio) or Ironite (Ironite Products Co., Scottsdale, Ariz.); Niemera speculated that such small differences would not be physiologically significant in terms of plant growth. Svenson and Witte (1992) showed that pine bark amended with $25 \%$ to $50 \%$ composted hardwood bark provided sufficient boron (B), $\mathrm{Fe}, \mathrm{Mn}$, and $\mathrm{Zn}$ for geranium (Pelargonium $\times$ hortorum L.) growth.

Research on micronutrient additions to container media and its effect on plant growth have found contrasting results. Rose and Wang (1999) reported no improvement in rhododendron (Rhododendron L. $\times$ 'Girards Scarlet') growth when adding compost or micronutrient fertilizer to a 3.0 pine bark : 1.0 hardwood bark : 1.0 peat : 0.2 sand (by volume) medium compared with a nonamended control. In contrast, vinca [Catharanthus roseus (L.) G. Don] shoot length and dry weight were greatest in a peat-based media with sulfated micronutrients $(\mathrm{pH}$ not adjusted) or chelated micronutrients $(\mathrm{pH}$ adjusted to 5.5) compared with a nonamended control (Thomas and Latimer, 1995). Wright et al. (1999) analyzed the effect of micronutrient and lime addition on substrate $\mathrm{pH}$ and growth of nine container tree species in pine bark; micronutrient additions resulted in the best growth responses for all species, whereas lime depressed growth. Micronutrients increased growth when $\mathrm{pH}$ was higher than 5.2 and lime had been applied.

Douglas fir bark in the PNW is used similarly to pine bark in the southeast U.S. Both bark types are irrigated frequently, fertilized with similar products and rates, and mixed with similar components (sand, peatmoss, and so on). Despite similarities in these two resources, several chemical properties of DFB have been found to differ from other conifer barks. For example, bark $\mathrm{pH}$, nitrogen $(\mathrm{N})$, phosphorous $(\mathrm{P})$, potassium $(\mathrm{K})$, calcium $(\mathrm{Ca})$, magnesium $(\mathrm{Mg})$, and $\mathrm{C} / \mathrm{N}$ ratio differ among Douglas fir, ponderosa pine, and redwood (Bollen, 1969). Research conducted on pine bark with respect to nursery container nutrition cannot be assumed applicable to DFB.

To accurately assess micronutrient status of DFB substrates, a reliable protocol must be used that provides values that are correlated to or predictive of plant micronutrient status. Most laboratories use water extraction for micronutrient analysis, although Warncke (1986) advocates the use of diethylenetriaminepentaacetic acid (DTPA) extraction primarily because it yields larger values.

The objectives of this study were: 1) to evaluate micronutrient availability in fresh and aged DFB; 2) to determine the effect of micronutrient amendments on substrate and 
foliar micronutrient levels; and 3) to compare water and DTPA extractions for measuring micronutrient availability in DFB substrates. Our initial hypothesis was that DFB alone provides sufficient micronutrients for annual vinca.

\section{Materials and Methods}

Expt. 1. On 5 May 2005, uniform plugs of annual vinca [Catharanthus roseus (L.) G. Don 'Peppermint Cooler'] $\approx 10 \mathrm{~cm}$ tall were transplanted to \#1 containers $(2.8 \mathrm{~L})$ filled with DFB. Treatments were arranged in a $2 \times 3$ factorial with two DFB ages (fresh and aged) and three micronutrient sources. All bark was ground with a hammer mill and passed through a $0.95-\mathrm{cm}$ screen. Micronutrient sources included incorporating $10 \%$ by volume yard debris compost $(2.1 \mathrm{~N}-0.2 \mathrm{P}-$ $0.5 \mathrm{~K}-1.4 \mathrm{Ca}-0.3 \mathrm{Mg}-0.001 \mathrm{~B}-0.004 \mathrm{Cu}-0.9 \mathrm{Fe}-$ $0.03 \mathrm{Mn}-0.01 \mathrm{Zn}$ ) (Rexius Co., Eugene, Ore.), $0.9 \mathrm{~kg} \cdot \mathrm{m}^{-3}$ Micromax micronutrient fertilizer $(6 \mathrm{Ca}-3 \mathrm{Mg}-12 \mathrm{~S}-0.10 \mathrm{~B}-1 \mathrm{Cu}-17 \mathrm{Fe}-2.5 \mathrm{Mn}-$ $0.05 \mathrm{Mo}-1 \mathrm{Zn}$ ) (The Scotts Co.), or DFB alone (nonamended). Yard debris was composted for 12 weeks and passed through a $1.6-\mathrm{cm}$ screen. All treatments were amended with $1.8 \mathrm{~kg} \cdot \mathrm{m}^{-3}$ dolomitic limestone $(22.7 \mathrm{Ca}-$ $11.8 \mathrm{Mg}, 113$ calcium carbonate equivalence) (Chemical Lime Lhoist Group, Salinas, Calif.) and $8.9 \mathrm{~kg} \cdot \mathrm{m}^{-3}$ Osmocote $(14 \mathrm{~N}-4.2 \mathrm{P}-11.6 \mathrm{~K})$ (The Scotts Co.). The experiment was conducted in a greenhouse at Oregon State Univ., Corvallis, Ore. Heat and vent greenhouse temperatures were set at 16 and $21{ }^{\circ} \mathrm{C}$, respectively. At 6 weeks after potting (WAP), all plants were measured for foliar color using a SPAD 502 Chlorophyll Meter (Minolta Camera Co., Ramsey, N.J.) and shoot dry weight (SDW) by drying in an oven at $60{ }^{\circ} \mathrm{C}$ for $72 \mathrm{~h}$. Recently mature leaves (Mills and Jones, 1996) and the entire growing media were sampled from each plant. Foliar samples were analyzed for N, $\mathrm{P}, \mathrm{K}, \mathrm{Ca}, \mathrm{Mg}, \mathrm{S}, \mathrm{B}, \mathrm{Fe}, \mathrm{Mn}, \mathrm{Cu}$, and $\mathrm{Zn}$. Foliar $\mathrm{N}$ was determined by combustion analysis using a $1500 \mathrm{~N}$ analyzer (Carlo Erba, Milan, Italy). The remaining nutrients were determined by inductively coupled plasma-emission spectrometry (ICP) (Thermo Jarrel Ash, Offenbach, Germany). Media samples were analyzed for the same nutrients plus $\mathrm{pH}$ and electrical conductivity (EC) using a saturated media extract (SME) method with water and DTPA (Warncke, 1998; Gavlak et al., 2003). Each treatment was replicated seven times in a completely randomized design.

Expt. 2. On 28 July 2005, Expt. 1 was repeated with 16 replications. Eight vinca plants were sampled 5 and 8 WAP each; otherwise, this experiment was conducted similarly to the previous one.

Data from both experiments were subjected to analysis of variance (SAS Institute, 1982) and repeated-measures analysis in Expt. 2 when data were collected twice over time. Measured values for each nutrient parameter are compared with recommended values for substrates (Warncke, 1998) and foliage (Wilkins, 1988).

\section{Results}

Expt. 1. At the conclusion of the study, all plants were healthy and vigorous. There were no differences in SDW or foliar color regardless of DFB age and micronutrient source (Table 1).

Bark age and amendments affected substrate $\mathrm{pH}$, although the range of substrate $\mathrm{pH}$ was narrow (4.7-5.1, Table 1). Substrate $\mathrm{pH}$ was lower in aged DFB compared with fresh DFB. Within each DFB age, containers amended with compost had higher substrate $\mathrm{pH}$ than nonamended or Micromax-amended substrates. DTPA-extractable micronutrients in the substrate were not correlated with substrate $\mathrm{pH}$. The highest correlation coefficient was for $\mathrm{B}(\mathrm{r}=-0.380)$, but even this correlation was weak. Micronutrients in soils and substrates are often correlated to substrate $\mathrm{pH}$ (Tisdale et al., 1985). The narrow $\mathrm{pH}$ range in this study is most likely responsible for low correlation coefficients.

DTPA B was higher in aged DFB than fresh DFB, but all were below that recommended for potting media. Within each DFB age, Micromax resulted in higher substrate $B$ levels than compost, and compost resulted in higher B levels than DFB alone. Foliar B was correlated to substrate B extracted with DTPA and water (Table 2). Foliar B concentration was below recommended levels in nonamended fresh DFB.

Substrate DTPA Fe was higher in nonamended aged than fresh DFB. All treatments had adequate substrate Fe. However, all foliar $\mathrm{Fe}$ remained below the recommended range. Foliar $\mathrm{Fe}$ was not correlated to substrate Fe extracted with either DTPA or water (Table 2). Bark age interacted with micronutrient source to affect foliar Fe. Micronutrient source did not influence foliar $\mathrm{Fe}$ when added to aged DFB, although compost increased foliar Fe in fresh DFB.

DTPA substrate Mn was higher in fresh than in aged DFB, with the exception of nonamended DFB. Substrate Mn was within the recommended range for all treatments. Foliar Mn was not correlated to DTPA Mn; however, it was highly correlated to water Mn (Table 2). Water substrate Mn was higher in fresh than in aged DFB (data not presented) with the same trend observed in vinca foliage. Within DFB age, Micromax had the highest substrate water Mn (data not presented) and nonamended DFB resulted in the lowest extractable levels. Foliar Mn levels were sufficient in both barks. Micromax increased foliar Mn over nonamended vinca. Micromax in fresh DFB increased foliar Mn to twice the recommended levels.

DTPA substrate $\mathrm{Cu}$ was higher in fresh than in aged DFB when amended with Micromax, and all treatments were within or above the recommended range. Foliar $\mathrm{Cu}$ was correlated to DTPA $\mathrm{Cu}$ but not correlated to water $\mathrm{Cu}$ (Table 2). High DTPA $\mathrm{Cu}$ in Micromax treatments resulted in adequate foliar $\mathrm{Cu}$, whereas adequate DTPA $\mathrm{Cu}$ in the other treatments resulted in less-thanrecommended foliar $\mathrm{Cu}$.
Substrate DTPA Zn was higher in fresh than in aged DFB. Substrate Zn was below the recommended range, except for Micromax treatments. Foliar $\mathrm{Zn}$ was correlated with DTPA $\mathrm{Zn}$ and water $\mathrm{Zn}$ (Table 2). Low DTPA $\mathrm{Zn}$ in nonamended and compost treatments resulted in sufficient foliar $\mathrm{Zn}$ across DFB age. Acceptable DTPA Zn from Micromax caused high foliar $\mathrm{Zn}$ in both DFB ages.

Expt. 2. At 5 WAP, micronutrient source did not influence plants size in fresh DFB; however, compost increased plant size in aged DFB (Table 3). At 8 WAP, the aged DFB plants were larger than fresh DFB as a result of differences in $\mathrm{N}$ availability (data not shown). Research concurrent with this project has documented greater $\mathrm{N}$ immobilization in fresh than aged DFB (Buamscha et al., 2005). In fresh DFB, nonamended vinca were smaller than those amended with compost and Micromax. Aged DFB treatments showed no differences in size between nonamended and amended plants.

Neither DFB age nor micronutrient source affected SPAD levels at 5 and 8 WAP, although visual observations at 8 WAP indicated a darker green color in aged versus fresh DFB (data not shown). Altland et al. (2002) previously reported the inability of SPAD meters to accurately predict $\mathrm{N}$ status of annual bedding plants. SPAD meter measurements should be interpreted with caution. No plants developed growth or foliar color symptoms that could be related to micronutrient deficiency or toxicity.

Bark age and micronutrient source interacted to affect substrate $\mathrm{pH}$ at 5 and 8 WAP. Similar to Expt. 1, pH differences among treatments were minor and correlations between substrate $\mathrm{pH}$ and extractable micronutrients (water or DTPA) were weak ( $\mathrm{r} \leq$ $0.377)$.

Repeated-measures analysis indicates that substrate and foliar $\mathrm{B}, \mathrm{Fe}, \mathrm{Mn}, \mathrm{Cu}$, and $\mathrm{Zn}$ decreased between 5 and 8 WAP $(P<$ $0.0001)$. The observed reduction in substrate nutrients may be a consequence of plant uptake and leaching.

At 5 and 8 WAP, compost and Micromax increased substrate B (water and DTPA) in both DFB ages compared with nonamended treatments (Table 3). Similar to Expt. 1, foliar B was correlated with DTPA and water B (Table 2), explaining similarity of treatment effects on substrate and foliar B.

Bark age effect on DTPA-extractable Fe at both sampling dates was similar to Expt. 1 . Vinca in aged DFB had higher foliar Fe levels than in fresh DFB, which mimicked the substrate treatment response. Foliar Fe was not correlated to water $\mathrm{Fe}$ and weakly correlated to DTPA Fe (Table 2).

Substrate DTPA Mn was similar between fresh and aged DFB at 5 WAP. At 8 WAP, fresh DFB was higher in Mn than aged DFB. Similar to Expt. 1, substrate $\mathrm{Mn}$ was the within recommended range across treatments and sampling dates. Foliar Mn was again more correlated to water Mn than to DTPA Mn (Table 2). Only Micromax increased 
Table 1. Annual vinca shoot dry weight (SDW), SPAD, and substrate and foliar micronutrients resulting from two bark ages and three micronutrient sources (Expt. 1).

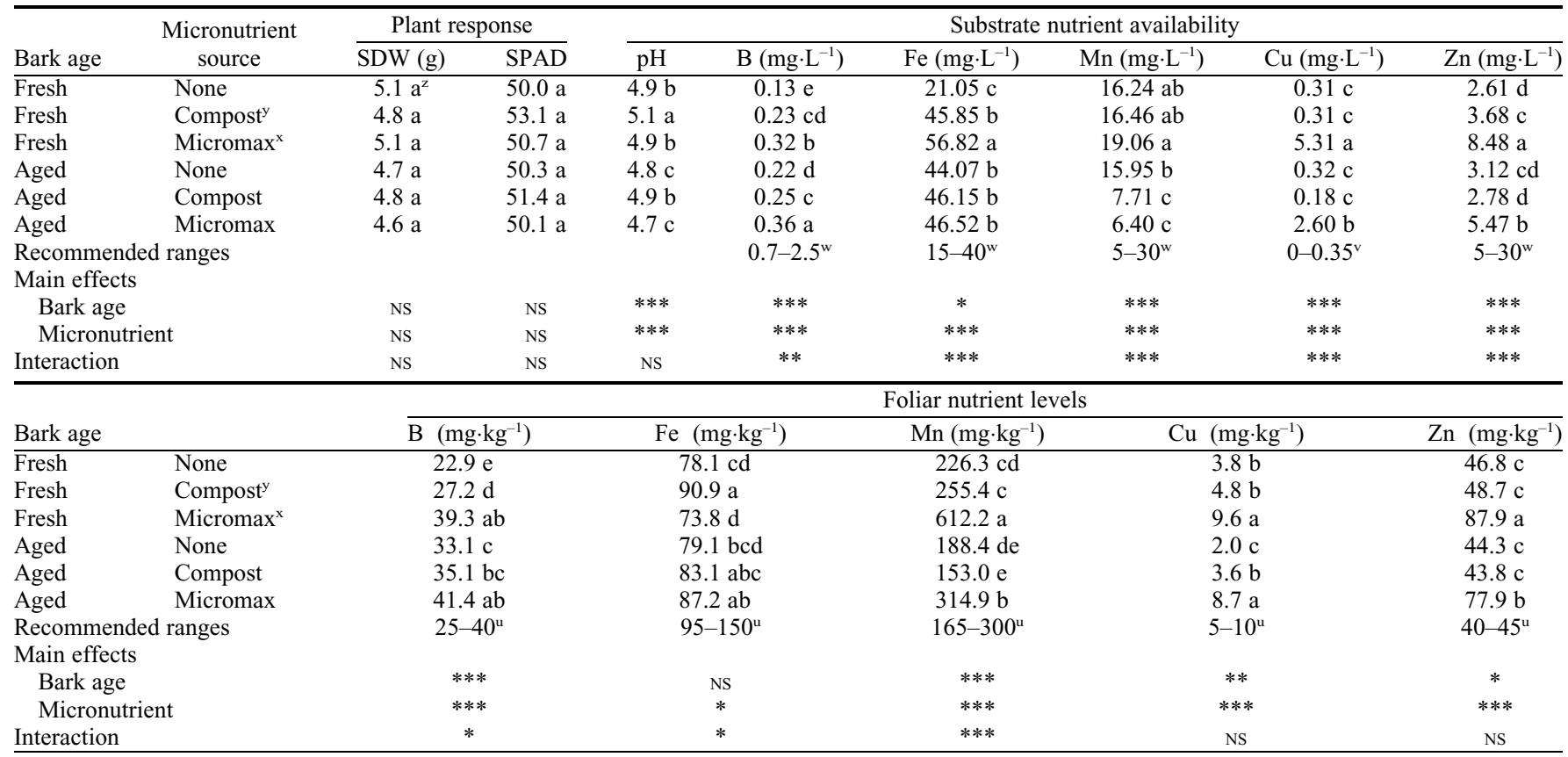

${ }^{z}$ Means with different letters within a column and collection date are significantly different separated by least significant difference test $(\alpha \leq 0.05)$.

y Ten percent by volume yard debris compost.

${ }^{x} 0.9 \mathrm{~kg} \cdot \mathrm{m}^{-3}$ Micromax micronutrient fertilizer.

wWarncke, D.D. 1998. Recommended test procedure for greenhouse growth media, p. 34-37. In: W.C. Dahnke (ed.), Recommended chemical soil test procedures for the North Central region. North Central Reg. Res. Pub. No. 221. Miss. Agr. Expt. Stat. SB 1001.

${ }^{v}$ Guidelines provided by Brookside Laboratories (New Knoxville, Ohio).

"Wilkins, H.F. 1988. University of Minnesota-Tissue analysis standards. Minnesota St. Florist Bulletin. Vol. 37 , No. 6.

Ns, ${ }^{* * *, * * *}$ Nonsignificant or significant at $P \leq 0.05,0.01$, and 0.001 .

Substrate $\mathrm{pH}$ and micronutrients analyzed with a saturated media extract using water and diethylenetriaminepentaacetic acid, respectively.

Foliar nutrients expressed on a dry weight basis.

substrate water Mn and foliar Mn. Foliar Mn levels were within or above the recommended range across all treatments.

Foliar $\mathrm{Cu}$ was more correlated to DTPA than water $\mathrm{Cu}$ (Table 2). Like in Expt. 1, Micromax resulted in excessive DTPA $\mathrm{Cu}$, but foliar $\mathrm{Cu}$ was within the recommended range across DFB ages. Fresh and aged nonamended barks resulted in DTPA $\mathrm{Cu}$ levels within or just above recommended ranges but deficient foliar $\mathrm{Cu}$.

Substrate DTPA Zn was higher in aged than in fresh DFB at 5 WAP, whereas no differences existed at $8 \mathrm{WAP}$. Independent of DFB age and sampling date, DTPA Zn were deficient, near the lower limit, and adequate for the nonamended, compost, and Micromax treatments, respectively. Foliar $\mathrm{Zn}$ was correlated to DTPA and water Zn (Table 2). Low DTPA $\mathrm{Zn}$ in the nonamended treatments

Table 2. Correlation (r) between each foliar and water or diethylenetriaminepentaacetic acid (DTPA)-extractable substrate micronutrients in annual vinca.

\begin{tabular}{lrrrrr}
\hline & \multicolumn{2}{c}{ Expt. 1 } & & \multicolumn{2}{c}{ Expt. 2 } \\
\cline { 2 - 3 } \cline { 5 - 6 } Nutrient & Water & DTPA & & Water & DTPA \\
\hline $\mathrm{B}$ & 0.711 & 0.738 & & 0.674 & 0.677 \\
$\mathrm{Fe}$ & -0.309 & -0.097 & & -0.043 & 0.602 \\
$\mathrm{Mn}$ & 0.927 & 0.297 & & 0.678 & 0.388 \\
$\mathrm{Cu}$ & 0.301 & 0.789 & & 0.276 & 0.677 \\
$\mathrm{Zn}$ & 0.923 & 0.760 & & 0.688 & 0.793 \\
\hline
\end{tabular}

resulted in higher-than-recommended foliar $\mathrm{Zn}$. Micromax increased foliar $\mathrm{Zn}$ far higher than recommended, although substrate $\mathrm{Zn}$ was within the recommended range.

\section{Discussion}

Douglas fir bark without amendment provides sufficient micronutrients for annual vinca over a 2-month period. The findings are similar to research of Niemiera (1992), Svenson and Witte (1992), and Rose and Wang (1999) in pine bark substrates. Substrate and foliage micronutrients declined from 5 to 8 WAP and might decline even more over the course of a long production period (several months) for woody crops. Others have found that substrate micronutrient supply over the course of a growing season is relatively constant and unaffected by irrigation (Broschat and Donselman, 1985; Niemiera, 1992). Substrate $\mathrm{pH}$ was low in this experiment. Because micronutrients are responsive to substrate $\mathrm{pH}$, elevated $\mathrm{pH}$ might reduce micronutrient levels and impact plant growth more than what occurred in this study. Increase in substrate $\mathrm{pH}$ resulting from water alkalinity might gradually reduce micronutrient availability in woody crops with longer production cycles. Until more research addresses longevity of micronutrient availability in DFB and responsiveness to substrate $\mathrm{pH}$, it can only be concluded that DFB is a reliable micronutrient source for crops with short production cycles being grown at $\mathrm{pH} 4.7$ to 5.7.

Nonamended plants in fresh bark were smaller than amended ones at the end of Expt. 2. Micronutrient nutrition cannot explain these growth differences for two reasons: 1) compost and nonamended plants had similar foliar nutrients levels except for B, and 2) Micromax-amended plants had higher foliar $\mathrm{Ca}, \mathrm{Mg}, \mathrm{S}$ (data not presented), $\mathrm{Mn}, \mathrm{Cu}$, and $\mathrm{Zn}$ than nonamended; however, the same trend occurred in aged DFB and did not affect plant growth. Foliar $\mathrm{N}$ was reduced in plants growing in fresh compared with aged DFB (3.2 versus 4.7\%, respectively, data not presented). Micronutrient source did not affect $\mathrm{N}$ and thus does not explain differences observed between the two DFB ages.

No broad generalization can be made as to which DFB age (fresh or aged) provides greater micronutrient nutrition. After 8 weeks, plants in both barks had the highest foliar levels of $\mathrm{Mn}, \mathrm{Cu}$, and $\mathrm{Zn}$ when amended with Micromax. Higher foliar micronutrient concentrations did not improve crop dry weight or color. Within both DFB ages, plants amended with compost and Micromax were similar in size and color. Similarly, Rose and Wang (1999) found no growth differences between treatments amended with compost and micronutrient fertilizers. 
Table 3. Annual vinca shoot dry weight (SDW), SPAD, and substrate and foliar micronutrients resulting from two bark ages and three micronutrient sources (Expt. 2).

\begin{tabular}{|c|c|c|c|c|c|c|c|c|c|}
\hline \multirow[b]{2}{*}{ Bark age } & \multirow{2}{*}{$\begin{array}{l}\text { Micronutrient } \\
\text { source }\end{array}$} & \multicolumn{2}{|c|}{ Plant response } & \multicolumn{6}{|c|}{ Substrate nutrient availability } \\
\hline & & $\overline{\mathrm{SDW}}(\mathrm{g})$ & SPAD & $\mathrm{pH}$ & $\mathrm{B}\left(\mathrm{mg} \cdot \mathrm{L}^{-1}\right)$ & $\mathrm{Fe}\left(\mathrm{mg} \cdot \mathrm{L}^{-1}\right)$ & $\mathrm{Mn}\left(\mathrm{mg} \cdot \mathrm{L}^{-1}\right)$ & $\mathrm{Cu}\left(\mathrm{mg} \cdot \mathrm{L}^{-1}\right)$ & $\mathrm{Zn}\left(\mathrm{mg} \cdot \mathrm{L}^{-1}\right)$ \\
\hline & \multicolumn{9}{|c|}{ Data collected $5 \mathrm{WAP}^{\mathrm{t}}$} \\
\hline Fresh & None & $4.6 b^{z}$ & $59.4 \mathrm{a}$ & $5.6 \mathrm{a}$ & $0.14 \mathrm{~d}$ & $29.78 \mathrm{~d}$ & $18.88 \mathrm{c}$ & $0.48 \mathrm{~cd}$ & $3.51 \mathrm{~d}$ \\
\hline Fresh & Compost $^{\mathrm{y}}$ & $4.7 \mathrm{bc}$ & $57.8 \mathrm{a}$ & $5.7 \mathrm{a}$ & $0.21 \mathrm{c}$ & $57.02 \mathrm{c}$ & $27.23 \mathrm{ab}$ & $0.74 \mathrm{c}$ & $5.42 \mathrm{c}$ \\
\hline Fresh & $\operatorname{Micromax}^{\mathrm{x}}$ & $4.9 \mathrm{ab}$ & $59.4 \mathrm{a}$ & $5.3 \mathrm{~b}$ & $0.26 \mathrm{~b}$ & $86.60 \mathrm{~b}$ & $28.05 \mathrm{ab}$ & $4.90 \mathrm{a}$ & $13.39 \mathrm{~b}$ \\
\hline Aged & None & $4.2 \mathrm{c}$ & $58.9 \mathrm{a}$ & $5.2 \mathrm{c}$ & $0.21 \mathrm{c}$ & $\times 62.26 \mathrm{c}$ & $18.31 \mathrm{c}$ & $0.37 \mathrm{~d}$ & $3.95 \mathrm{~d}$ \\
\hline Aged & Compost & $5.5 \mathrm{a}$ & $59.4 \mathrm{a}$ & $5.3 \mathrm{bc}$ & $0.31 \mathrm{a}$ & $91.06 \mathrm{~b}$ & $25.30 \mathrm{~b}$ & $0.71 \mathrm{c}$ & $5.95 \mathrm{c}$ \\
\hline \multirow[t]{2}{*}{ Aged } & Micromax & $4.4 \mathrm{bc}$ & $61.4 \mathrm{a}$ & $5.3 \mathrm{bc}$ & $0.33 \mathrm{a}$ & $113.48 \mathrm{a}$ & $28.50 \mathrm{a}$ & $4.20 \mathrm{~b}$ & $14.37 \mathrm{a}$ \\
\hline & \multicolumn{9}{|c|}{ Data collected 8 WAP } \\
\hline Fresh & None & $7.9 \mathrm{c}$ & $53.3 \mathrm{a}$ & $5.3 \mathrm{ab}$ & $0.13 \mathrm{~d}$ & $27.07 \mathrm{~d}$ & $16.15 \mathrm{c}$ & $0.37 \mathrm{~d}$ & $2.79 \mathrm{c}$ \\
\hline Fresh & Compost & $11.1 \mathrm{~b}$ & $52.1 \mathrm{a}$ & $5.4 \mathrm{a}$ & $0.18 \mathrm{c}$ & $43.84 \mathrm{c}$ & $22.47 \mathrm{a}$ & $0.61 \mathrm{c}$ & $4.46 \mathrm{~b}$ \\
\hline Fresh & Micromax & $11.1 \mathrm{~b}$ & $51.2 \mathrm{a}$ & $5.2 \mathrm{bc}$ & $0.19 \mathrm{bc}$ & $54.92 \mathrm{~b}$ & $18.96 \mathrm{~b}$ & $3.44 \mathrm{a}$ & $9.68 \mathrm{a}$ \\
\hline Aged & None & $12.7 \mathrm{a}$ & $50.0 \mathrm{a}$ & $5.1 \mathrm{~d}$ & $0.20 \mathrm{~b}$ & $56.23 \mathrm{~b}$ & $12.25 \mathrm{~d}$ & $0.33 \mathrm{~d}$ & $3.27 \mathrm{c}$ \\
\hline Aged & Compost & $13.5 \mathrm{a}$ & $55.8 \mathrm{a}$ & $5.2 \mathrm{bc}$ & $0.27 \mathrm{a}$ & $70.24 \mathrm{a}$ & $16.74 \mathrm{bc}$ & $0.49 \mathrm{~cd}$ & $4.86 \mathrm{~b}$ \\
\hline Aged & Micromax & $12.0 \mathrm{ab}$ & $51.0 \mathrm{a}$ & $5.2 \mathrm{c}$ & $0.25 \mathrm{a}$ & $69.81 \mathrm{a}$ & $13.45 \mathrm{~d}$ & $2.97 \mathrm{~b}$ & $9.63 \mathrm{a}$ \\
\hline Recomm & ranges & & & & $0.7-2.5^{\mathrm{w}}$ & $15-40^{\mathrm{w}}$ & $5-30^{w}$ & $0-0.35^{\mathrm{v}}$ & $5-30^{w}$ \\
\hline \multicolumn{10}{|c|}{ Main effects } \\
\hline \multicolumn{2}{|c|}{ Bark age (B) } & $* * *$ & NS & $* * *$ & $* * *$ & $* * *$ & $* * *$ & $* * *$ & $* *$ \\
\hline \multicolumn{2}{|c|}{ Micronutrient source (M) } & $* * *$ & NS & $* * *$ & $* * *$ & $* * *$ & $* * *$ & $* * *$ & $* * *$ \\
\hline \multicolumn{2}{|c|}{$\mathrm{B} * \mathrm{M}$} & $* *$ & NS & $* * *$ & NS & $* *$ & NS & $* * *$ & NS \\
\hline \multicolumn{2}{|l|}{ Date (D) } & $* * *$ & $* * *$ & $* * *$ & $* * *$ & $* * *$ & $* * *$ & $* * *$ & $* * *$ \\
\hline \multicolumn{2}{|l|}{$B^{*} \mathrm{D}$} & $* * *$ & NS & $* *$ & NS & $*$ & $* * *$ & NS & NS \\
\hline \multicolumn{2}{|l|}{$M * D$} & NS & NS & NS & $* * *$ & $* * *$ & $* * *$ & $* * *$ & $* * *$ \\
\hline \multicolumn{2}{|l|}{$B * M * D$} & $* * *$ & NS & NS & NS & NS & NS & NS & NS \\
\hline \multicolumn{10}{|c|}{ Foliar nutrient levels } \\
\hline \multicolumn{2}{|l|}{ Bark age } & \multicolumn{2}{|c|}{$\mathrm{B}\left(\mathrm{mg} \cdot \mathrm{kg}^{-1}\right)$} & \multicolumn{2}{|c|}{$\mathrm{Fe}\left(\mathrm{mg} \cdot \mathrm{kg}^{-1}\right)$} & $\mathrm{Mn}\left(\mathrm{mg} \cdot \mathrm{kg}^{-1}\right)$ & $\mathrm{Cu}$ & $\left.\mathrm{kg}^{-1}\right)$ & $\mathrm{Zn}\left(\mathrm{mg} \cdot \mathrm{kg}^{-1}\right)$ \\
\hline & & & & & Data collec & $5 \mathrm{WAP}^{\mathrm{t}}$ & & & \\
\hline Fresh & None & & & & & $357.3 \mathrm{bc}$ & & & $58.5 \mathrm{c}$ \\
\hline Fresh & Compost $^{\mathrm{y}}$ & & & & $\mathrm{cd}$ & $306.3 \mathrm{c}$ & & & $57.4 \mathrm{c}$ \\
\hline Fresh & $\operatorname{Micromax}^{\mathrm{x}}$ & & & & & $561.7 \mathrm{a}$ & & & $102.6 \mathrm{a}$ \\
\hline Aged & None & & & & & $397.8 \mathrm{~b}$ & & & $70.9 \mathrm{~b}$ \\
\hline Aged & Compost & & & & & $380.0 \mathrm{~b}$ & & & $63.5 \mathrm{bc}$ \\
\hline Aged & Micromax & 36.1 & & 109. & & $585.3 \mathrm{a}$ & 8.7 & & $105.6 \mathrm{a}$ \\
\hline & & & & & Data colle & 8 WAP & & & \\
\hline Fresh & None & & & & & $228.8 \mathrm{c}$ & & & $47.6 \mathrm{c}$ \\
\hline Fresh & Compost & & & & & $202.3 \mathrm{c}$ & & & $44.8 \mathrm{c}$ \\
\hline Fresh & Micromax & & & & & 299.7 b & & & $70.3 \mathrm{~b}$ \\
\hline Aged & None & & & & & $252.7 \mathrm{bc}$ & & & $60.3 \mathrm{~b}$ \\
\hline Aged & Compost & & & & & $304.3 \mathrm{~b}$ & & & $65.0 \mathrm{~b}$ \\
\hline Aged & Micromax & & & & & $496.1 \mathrm{a}$ & & & $105.5 \mathrm{a}$ \\
\hline Recomm & ranges & & & & $50^{\mathrm{u}}$ & $165-300^{\mathrm{u}}$ & & & $40-45^{\mathrm{u}}$ \\
\hline Main effe & & & & & & & & & \\
\hline Bark age & & & & & & $* * *$ & & & $* * *$ \\
\hline Micronut & ource (M) & & & & & $* * *$ & & & $* * *$ \\
\hline $\mathrm{B} * \mathrm{M}$ & & & & & & NS & & & NS \\
\hline Date (D) & & & & & & $* * *$ & & & $* * *$ \\
\hline$B * D$ & & & & & & $* *$ & & & $* * *$ \\
\hline$M * D$ & & & & & & $* *$ & & & NS \\
\hline$\underline{B} * M^{*} \mathrm{D}$ & & & & & & $* *$ & & & $*$ \\
\hline
\end{tabular}

${ }^{\mathrm{z}}$ Means with different letters within a column and collection date are significantly different separated by least significant difference test $(\alpha \leq 0.05)$.

${ }^{y}$ Ten percent by volume yard debris compost.

${ }^{\mathrm{x}} 0.9 \mathrm{~kg} \cdot \mathrm{m}^{-3}$ Micromax micronutrient fertilizer.

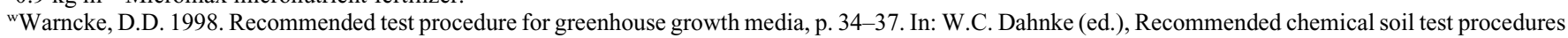
for the North Central region. North Central Reg. Res. Pub. No. 221. Miss. Agr. Expt. Stat. SB 1001.

${ }^{v}$ Guidelines provided by Brookside Laboratories (New Knoxville, Ohio).

"Wilkins, H.F. 1988. University of Minnesota—Tissue analysis standards. Minnesota St. Florist Bulletin. Vol. 37, No. 6.

'Weeks after planting.

Ns, ${ }^{*}, * *, * * *$ Nonsignificant or significant at $P \leq 0.05,0.01$, and 0.001 .

Substrate $\mathrm{pH}$ and micronutrients analyzed with a saturated media extract using water and diethylenetriaminepentaacetic acid, respectively.

Foliar nutrients expressed on a dry weight basis.

Guidelines for soilless substrates developed by Warncke (1998) do not always match foliar guidelines developed for individual crops. Warncke's guidelines indicate that nonamended fresh and aged DFB do not have adequate $\mathrm{B}$ and $\mathrm{Zn}$ by 8 WAP. However, foliar guidelines for annual vinca by Wilkins (1988) indicate that fresh and aged DFB supplies sufficient foliar Zn. Specific foliar guidelines for annual vinca are probably more reliable than general substrate guidelines; however, Wilkins' foliar micronutrient guidelines for annual vinca are not always supported by our observations. For example, in Expt.1, Micromax increased foliar Mn in fresh DFB and foliar $\mathrm{Zn}$ in both barks to levels considerably higher than recommended, although plants did not show symptoms of Mn or Zn toxicity. A possible explanation for this discrepancy is that Wilkins' foliar guidelines were not defined by vinca growth stage.

Warncke (1998) recommends DTPA to enhance the extraction of $\mathrm{Zn}, \mathrm{Mn}$, and Fe. In this study, we saw increased extraction of the mentioned micronutrients plus $\mathrm{Cu}$ when using DTPA compared with water. Increased 
extraction of a particular micronutrient does not necessarily correlate with solution concentration available for plant absorption. Handreck and Black (2002) also recommend DTPA because of increased $\mathrm{Fe}$ in substrates with increasing $\mathrm{Fe}$ amendment rates. However, increased $\mathrm{Fe}$ would be expected in substrates with increased amendment rates, and again this does not imply increased nutrient availability for plants. In agronomic crops, nutrient availability is measured with a variety of extractants with the most useful being that which correlates most closely to yield. Ornamental crops, and annual vinca in particular, do not produce a harvestable yield in terms of fruit or fiber. The best gauge of how well an extractant works (water or DTPA) with ornamental crops is how well it correlates to foliar nutrient levels. In this study, foliar Mn was more highly correlated with water $\mathrm{Mn}$ and foliar $\mathrm{Cu}$ with DTPA $\mathrm{Cu}$, whereas foliar B and $\mathrm{Zn}$ were correlated to both extractants. Rose and Wang (1999) reported a lack of correlation between foliar and substrate DTPA Fe, $\mathrm{Cu}, \mathrm{Zn}$, and B. More research is required to closely compare extractants for nutrient availability in DFB and other substrates.

In summary, these data demonstrate that DFB is an important source of micronutrients for container-grown crops. Boron and $\mathrm{Cu}$ may appear to be deficient depending on which set of guidelines or experimental results are considered. Longevity and $\mathrm{pH}$ responsiveness of micronutrient availability is still not known. These results cannot rule out recommendations for use of micronutrient amendments; however, they do suggest micronutrient availability in DFB be considered in container fertilizer management plans.

\section{Literature Cited}

Altland, J.E., C.H. Gilliam, J.H. Edwards, G.J. Keever, D.C. Fare, and J.L. Sibley. 2002. Rapid determination of nitrogen status in annual vinca. J. Environ. Hort. 20:189-194.

Bollen, W.B. 1969. Properties of tree barks in relation to their agricultural utilization . USDA For. Serv. Res. Paper PNW 77.

Broschat, T.K. and H.M. Donselman. 1985. Extractable $\mathrm{Mg}, \mathrm{Fe}, \mathrm{Mn}, \mathrm{Zn}$, and $\mathrm{Cu}$ from a peatbased container medium amended with various micronutrient fertilizers. J. Amer. Soc. Hort. Sci. 110:196-200.

Buamscha, G., J. Altland, D. Sullivan, and D. Horneck. 2005. Chemical and physical properties of Douglas fir bark used in container production. SNA Res. Conf. Vol. 50:29-32.

Gavlak, R., D. Horneck, R. Miller, and J. KotubyAmacher. 2003. Soil, plant, and water reference methods for the Western Region. 2nd Ed. WCC-103 Publication, Fort Collins, Colo.

Handreck, K. and N. Black. 2002. Growing media for ornamental plants and turf. Univ. of New South Wales Press Ltd., Sydney.

Harkin, J.M. and J.W. Rowe. 1971. Bark and its possible uses. USDA. For. Serv. For. Prod. Lab. Madison, Wis. Res. Note FPL-0.91.9 Mar. 2005. <http://www.fpl.fs.fed.us/documnts/ fplrn/fplrn091.pdf $>$.
Mills, H.A. and J.B. Jones. 1996. Plant analysis handbook II. MicroMacro Publishing, Athens, $\mathrm{Ga}$

Niemiera, A.X. 1992. Micronutrient supply from pine bark and micronutrient fertilizers. HortScience 27:272.

Rose, M.A. and H. Wang. 1999. Comparison of micronutrient sources for container Rhododendron. HortTechnology 9:220-224.

SAS Institute. 1982. SAS user's guide and SAS statistical procedures. SAS Inst., Cary, N.C

Svenson, S.E. and W.T. Witte. 1992. Ca, Mg, and micronutrient nutrition and growth of pelargonium in pine bark amended with composted hardwood bark. J. Environ. Hort. 10:125-129.

Thomas, P.A. and J.G. Latimer. 1995. Nutrient charge, composition of media and nitrogen form affect growth of vinca. J. Plant Nutr. 18:2127-2134

Tisdale, S.L., W.L. Nelson, and J.D. Beaton. 1985. Soil fertility and fertilizers, Fourth ed., Macmillan, N.Y.

Warncke, D.D. 1986. Analyzing greenhouse growth media by the saturation extraction method. HortScience 21:223-225.

Warncke, D. 1998. Recommended test procedure for greenhouse growth media, p. 34-37. In: W.C. Dahnke (ed.), Recommended chemical soil test procedures for the North Central region. North Central Reg. Res. Pub. No. 221. Miss. Agr. Expt. Stat. SB 1001.

Wilkins, H.F. 1988. University of MinnesotaTissue analysis standards. Minnesota St. Florist Bulletin. Vol. 37, No 6.

Wright, A.N., A.X. Niemiera, J.R. Harris, and R.D. Wright. 1999. Preplant lime and micronutrient amendments to pine bark affect growth of seedlings of nine container-grown tree species. HortScience 34:669-673. 